\title{
RISK FACTORS OF CHILDREN BEHAVIOR IN SCHISTOSOMYTHICAL TRANSFER IN TWO VILLAGES OF LINDU REGENCY, SIGI DISTRICT, CENTRAL SULAWESI IN 2017
}

\author{
Tri Sulistiyawati ${ }^{1}$, Budi Utomo ${ }^{2}$, Soeharto ${ }^{3}$ \\ ${ }^{1}$ Master Program of Tropical Medicine, ${ }^{2}$ Department of Public Health Sciences, ${ }^{3}$ Department of Internal Medicine, \\ Faculty of Medicine, Universitas Airlangga, Surabaya, Indonesia
}

\begin{abstract}
ABSTRAK
Anak-anak usia sekolah dasar sangat rentan terhadap schistosomiasis karena 60-70\% yang berusia 5-14 tahun melakukan banyak kegiatan di luar rumah. Dampak schistosomiasis pada anak-anak antara lain konsentrasi belajar yang kurang, anemia, dan gangguan pertumbuhan. Penelitian ini bertujuan untuk menggambarkan perilaku anak usia 7-12 tahun di desa Puro'o dan desa Tomado dalam mencegah transmisi schistosomiasis dan menentukan hubungan antara usia, perilaku seks komunitas dalam pencegahan schistosomiasis. Penelitian ini dilakukan di Desa Tomado dan Puro'o selama 3 bulan dari bulan Maret - Juni 2016. Desain penelitian adalah studi cross sectional. Sampel dalam penelitian ini adalah anak-anak berusia 7-12 tahun yang dipilih menggunakan stratified multistage random cluster sampling dalam tiga tahap: tahap pertama desa, tahap kedua sekolah dasar di desa, dan tahap ketiga rumah tangga yang dipilih dengan proporsional random sampling. Data dikumpulkan melalui wawancara menggunakan kuesioner dan observasi terstruktur serta dianalisis menggunakan uji chi-square. Responden yang memiliki pengetahuan kurang, kebanyakan berperilaku BAB/BAK jamban/WC (80\%), mencuci tangan dengan sabun setelah BAB/BAK (50\%), menggunakan alas kaki di luar rumah (86,5\%), dan bermain di sawah, rawa-rawa dan danau (67,3\%). Analisis hubungan antara pengetahuan dengan perilaku anak tidak menunjukkan hubungan yang signifikan $(p=0,114)$. Sebagai kesimpulan, anak usia $7-12$ tahun di Desa Puro'o dan Tomado sebagian besar memiliki perilaku kurang dalam mencegah transmisi schistosomiasis dan memiliki pengetahuan baik atau kurang. (FMI 2018;54:141-145)
\end{abstract}

Kata kunci: Anak 7-12 tahun; schistosomiasis; faktor risiko

\begin{abstract}
Children of primary school are particularly vulnerable to schistosomiasis because 60-70\% of them with age of 5-14 years do a lot of activity outside home. The impact of schistosomiasis in children are the lack of concentration in learning, anemia, and impaired growth. This study aimed to describe the behavior of children aged 7-12 years in Puro'o and Tomado Villages in preventing the transmission of schistosomiasis and to determine the correlation between age, sex behavior community in the prevention of schistosomiasis. The study was conducted in Tomado and Puro'o villages for 3 months from March to June 2016. This was a cross sectional study. The samples in this study were children aged 7-12 years, selected by stratified multistage random cluster sampling which was done in three phases: the first phase was the villages, the second phase was the primary school in the village, and the third stage was household selected by proportional random sampling. Data were collected through interview using a structured questionnaire and the observation was analyzed using chi-square test. Respondents who had less knowledge, mostly behave defecate/urinate (80\%) in latrine/WC, handwashing behavior with soap after defecating/urinating (50\%), wearing footwear outside the home (86.5\%), and playing in the rice fields, marshes and lakes (67.3\%). Analysis of the relationship between knowledge and child's behavior showed no significant relationship $(p=0.114)$. As a conclusion, children aged 7-12 years in Tomado and Puro'o villages mostly had less supportive behavior in preventing the transmission of schistosomiasis and had moderate or less reliable knowledge. (FMI 2018;54:141-145)
\end{abstract}

Keywords: Children aged 7-12 years; schistosomiasis; risk factors

Correspondence: Tri Sulisyawati, Master Program of Tropical Medicine, Faculty of Medicine, Universitas Airlangga, Surabaya, Indonesia. Email: trisulistiyawati.upaair@gmail.com

\section{INTRODUCTION}

Schistosomiasis is an acute and chronic infection by the blood worms (trematoda) of schistosoma genus. Schistosomiasis infection is transmitted by snails or water snails that live in water. The case of schistosomiasis in Indonesia is caused by Schistosoma japonicum which was first discovered in 1935 in Tomado Village, Lindu
District, Central Sulawesi. Schistosomiasis in Central Sulawesi is strongly related to agricultural and plantation environments as well as geographical conditions (Sudomo 2007). The prevalence of schistosomiasis in residents in Lindu is still quite high. This is due to the many breeding places/areas of snail, and community behavior is still mostly done on the snail focus area, such as farming, gardening, fishing, bathing, washing 
and defecating. The target of schistosomiasis eradication is to reduce the prevalence of schistosomiasis to $<1 \%$. The prevalence of primary school-aged children in Lindu sub-district by the end of 2015 has not been recorded as a whole and is considered unimportant by the community, government and related agencies. The long-term effects of schistosomiasis in children can cause considerable harm to sufferers and their families. Primary school-aged children are particularly vulnerable to schistosomiasis infections because $60-70 \%$ of children aged 5-14 years do more outdoor activities. Schistosomiasis result from lack of cleanliness, child habits in urinating, defecating, playing, swimming and fishing in snail focus areas. The impact of schistosomiasis in children, for example, is less concentration for learning, anemia, and growth disorders.

Lindu Regency is an endemic area of schistosomiasis in Central Sulawesi. The prevalence of schistosomiasis in the area during the last 5 years (2011-2015) has fluctuated depending on the coverage of stool survey, ie $2011 ; 2.5 \%$, in $2012 ; 1.13 \%$, in $2013 ; 0.79 \%$, in 2014 ; $1.01 \%$ and $2015 ; 1.25 \%$. Puro'o Village and Tomado Village are villages that always have a prevalence higher than $1 \%$.

Schistosomiasis is a public health problem. Its transmission distribution is largely determined by the various factors of agent, host, and environment (Natsir 1992). In agent side, Schistosoma japonicum living in the veins of human and mammalian in some tropical and sub tropical regions is able to survive and breed in the body. The survival of Schistosoma japonicum requires an intermediate snail. Oncomelania hupensi lindoensis snails penetrate human skin in contact with infected Schistosoma japonicum.

Hosts are an influential factor. Schistosomiasis can affect all ages and all sexes, relationship status, education level, and occupation. Knowledge, attitudes and actions can affect the decrease in the prevalence of schistosomiasis. Definitive hosts besides humans are mammals, such as dog, mice, cats, cows, buffalo, deer, horses, and pigs.

There are insufficient environmental sanitation and access to clean water. No provision of environmental health facilities is associated with the transmission of schistosomiasis. Geographical conditions, temperature and humidity, rainfall, sunlight, climate and topography of Lore-Lindu region strongly support the proliferation of Oncomelania hupensi lindoensis. These factors are interconnected with each other, and they also influence the increasing number of schistosomiasis cases.
The aim of this study was to identify the behavior of 712 year old children in Puro'o and Tomado villages in preventing the transmission of schistosomiasis and to find the correlation between age, sex, knowledge with behavior of children aged 7-12 years in preventing transmission of the disease.

\section{MATERIALS AND METHODS}

This was a cross sectional study. This study was conducted in two villages in Lindu Sub-district, Lindu Regency, Central Sulawesi, the villages Puro'o and Tomado. Interview using questionnaire and observation were conducted to observe the factors related to children aged 7-12 year behavior in preventing the transmission of schistosomiasis. The interview was conducted by visiting respondents' houses. The aspects observed included the environmental conditions surrounding the respondent's home, the ownership of latrines and the water sources.

The population in this study were elementary schoolage children in Puro'o and Tomado villages. The samples were selected by random sampling. The sample size was calculated using the Solvin formula. Based on the calculation, the required number of samples was 44 respondents in Puro'o Village and 52 respondents in Tomado Village. So, the total sample was as many as 96 respondents. Sampling was done by using multistage random sampling method. The data collected included characteristics, knowledge and behavior. Data obtained from the study were analyzed using univariate and bivariate analysis. To observe the correlation between age, sex and the level of knowledge with the behavior of children in preventing Schistosomiasis, the data analysis was perfomed using chi-square test.

Age groups of respondents were divided into three, 7-8 years, 9-10 years and 11-12 years. Sex was categorized into two: male and female. The respondents' knowledge level was measured by observing respondents' answers on schistosomiasis, including definition, causes, ways of transmitting, prevention and where to access schistosomiasis treatment. The behavior of children in transmission was categorized into two, namely unreliable and reliable behavior. Child behavior in preventing schistosomiasis included the habit of defecating, bathing, washing, using clean water, and wearing footwear.

\section{RESULTS}

After interviewing in the research area, the number of respondents who could be interviewed was 96 respondents, consisting of 44 respondents in Puro'o Village 
and 52 respondents in Tomado Village. Respondents interviewed were mostly female. Reviewed respondents' characteristics can be seen in Table 1 .

Based on the interviews, not all respondents knew correctly about schistosomiasis. Only a small proportion of respondents knew the definition of schistosomiasis, the cause of schistosomiasis, the way of schistosomiasis transmittion, and the way to prevent and where to seek for treatment for those who were infected with schisto- somiasis. Of the several questions asked, the cause of being infected with schistosomiasis was the subject widely known by respondents. The result of interview on the respondents' knowledge about schistosomiasis in Puro'o Village and Tomado Village can be seen in Table 2. The results of interview about the behavior of 7-12 year old children in Puro'o and Tomado villages in preventing the transmission of schistosomiasis can be seen in Table 3.

Table 1. Respondents' characteristics in Puro'o and Tomado Villages, Lindu Regency, Central Sulawesi, 2016

\begin{tabular}{cccccc}
\hline \multirow{2}{*}{ No } & Respondents' & \multicolumn{2}{c}{ Puro'o } & \multicolumn{2}{c}{ Tomado } \\
\cline { 3 - 6 } & characteristics & $\mathrm{n}=44$ & $\%$ & $\mathrm{n}=52$ & $\%$ \\
\hline 1 & Age & & & & \\
& 7-8 years old & 14 & 32.0 & 17 & 17.0 \\
& $9-10$ years old & 16 & 36.0 & 13 & 35.0 \\
& 11-12 years old & 14 & 32.0 & 22 & 48.0 \\
\multirow{2}{*}{2} & & & & \\
& Sex & 27 & 61.4 & 29 & 55.8 \\
& Male & 17 & 38.6 & 23 & 44.5 \\
\hline & Female & & & & \\
\hline
\end{tabular}

Table 2. Respondents' knowledge on schistosomiasis in Puro'o and Tomado Villages, Lindu Regency, Central Sulawesi, 2016

\begin{tabular}{llcccc}
\hline \multirow{2}{*}{ No } & \multirow{2}{*}{ Respondents' knowledge } & \multicolumn{2}{c}{ Puro'o } & \multicolumn{2}{c}{ Tomado } \\
\cline { 3 - 6 } & & $\mathrm{n}=44$ & $\%$ & $\mathrm{n}=52$ & $\%$ \\
\hline 1 & Schistosomiasis definition & 22 & 50 & 15 & 28.8 \\
2 & Schistosomiasis cause & 24 & 54.5 & 21 & 40.4 \\
3 & Schistosomiasis transmission & 22 & 50 & 22 & 42.3 \\
4 & Schistosomiasis prevention & 16 & 36.4 & 37 & 71.2 \\
5 & Schistosomiasis place of treatment & 16 & 36.4 & 37 & 71.2 \\
\hline
\end{tabular}

Table 3. Child behavior in preventing transmission of schistosomiasis in Puro'o and Tomado Villages, Sigi District, Central Sulawesi, 2016

\begin{tabular}{|c|c|c|c|c|c|}
\hline \multirow{2}{*}{ No } & \multirow{2}{*}{ Respondents' behaviors } & \multicolumn{2}{|c|}{ Puro'o } & \multicolumn{2}{|c|}{ Tomado } \\
\hline & & $\mathrm{n}=44$ & $\%$ & $\mathrm{n}=52$ & $\%$ \\
\hline \multirow[t]{4}{*}{1} & Knowledge & & & & \\
\hline & Less reliable & 3 & 6.8 & 3 & 5.8 \\
\hline & Moderate & 28 & 63.6 & 29 & 55.7 \\
\hline & Reliable & 13 & 29.5 & 20 & 38.5 \\
\hline \multirow[t]{4}{*}{2} & Defecating/urinating in latrines/WC & & & & \\
\hline & No & 0 & 0 & 3 & 5.8 \\
\hline & Sometimes & 0 & 0 & 7 & 13.5 \\
\hline & Yes & 44 & 100 & 42 & 80.7 \\
\hline \multirow[t]{4}{*}{3} & $\begin{array}{l}\text { Washing hands with soap after } \\
\text { defecating/urinating }\end{array}$ & & & & \\
\hline & No & 2 & 4.5 & 5 & 9.6 \\
\hline & Sometimes & 6 & 13.6 & 21 & 40.4 \\
\hline & Yes & 36 & 81.1 & 21 & 50 \\
\hline \multirow[t]{4}{*}{4} & Wearing footwears outside home & & & & \\
\hline & No & 4 & 9.1 & 0 & 0 \\
\hline & Sometimes & 5 & 11.4 & 7 & 13.5 \\
\hline & Yes & 35 & 79.5 & 45 & 86.5 \\
\hline \multirow[t]{4}{*}{5} & $\begin{array}{l}\text { Playing in rice fields, marshes, and } \\
\text { ponds }\end{array}$ & & & & \\
\hline & No & 11 & 25 & 35 & 67.3 \\
\hline & Sometimes & 6 & 13.6 & 14 & 26.9 \\
\hline & Yes & 27 & 61.4 & 3 & 5.8 \\
\hline
\end{tabular}


The results showed a non-significant correlation $(\mathrm{p}=0.849)$. Most of the less $(5.8 \%)$, moderate $(55.7 \%)$ and high $(38.5 \%)$ educated children had poor behavior in preventing schistosomiasis transmission. Respondents who had less knowledge mostly defecated and urinated in latrines/WC $(80 \%)$. They used soap after defecating/urinating (50\%), using footwears outdoor $(86.5 \%)$, and playing in rice fields, marshes and lakes $(67.3 \%)$. Analysis of the relationship between knowledge and behavior of children showed a non-significant relationship $(\mathrm{p}=0.114)$.

\section{DISCUSSION}

A study conducted in Puro'o and Tomado villages showed that the prevalence of schistosomiasis was highest in the children aged 11-12 years old. The level of knowledge in these children about schistosomiasis was very low. Most of the respondents did not know about schistosomiasis and its transmission media. The villages apparently still required more activities. This is in line with research conducted on the improvement of community participation in medicine, where the results showed that repeated counseling can increase public knowledge about the disease.

Behavior prevention is a response to prevent a disease, including the behavior of not to transmit disease to others. Most people in Puro'o and Tomado villages defecated in latrines, but bathing and washing activities were done nearby water-well. Transmission of schistosomiasis in the Lindu Plain relates to people's bathing habits, washing in rivers, traveling to focus areas, utilizing water sources, washing feet and hands in rivers and swimming (Rosmini 2009). Schistosomiasis transmission occurs due to contact between humans and waters or entering the waters infected with schistosoma, leading to an increase in schistosemiasis (Natsir 1992).

One attempt to prevent the occurrence of schistosomiasis transmission is to avoid direct contact with infected waters, for example using rubber boots. The results of the analysis showed that there was no significant relationship. In addition, there might be other influencing factors, such as local culture and customs, which were not analyzed in this study. Behavior is motivated by three main factors, the predisposing factors, supporting factors and strengthening or encouraging factors. The results showed that people's behavior was still less reliable in people either with low or high education, so that the direction of the intervention is targeted to population with all levels of education both low and high.
In this analysis, knowledge was not significant related to behaviors in preventing transmission although the proportion of behaviors was lower in the group with less knowledge $(5.8 \%)$, moderate $(55.7 \%)$ and high $(38.5 \%)$. The results of this study were not in accordance with the results of a research which stated that the behavior of communities in support or prevent the occurrence of transmission of disease is strongly influenced by the knowledge of the community about the disease (Kasnodiharjo 1997). Knowledge is one of the internal factors that can affect the formation of behavior. Reliable knowledge of a disease will provide effect to actions that support the prevention of transmission of the disease (Murti 2006). Knowledge-based behavior will last longer than behavior not based on knowledge. Theoretically, knowledge can indeed support the formation of behavior, but nevertheless, in fact there are other factors that may affect behavior, such as local environmental, cultural and customary factors not covered by this study. There has been more intervention towards knowledge upgrading, whereas other interventions are needed not just in terms of knowledge, but the need for a supportive/conducive environment, cultural support and local traditions and perceived awareness and needs to be able to change behavior.

To support the success of the eradication of schistosomiasis, it is necessary to change the behavior of the people. In order to behave well, the community sometimes requires not only positive knowledge and attitude, and facilities support, but also examples, references from community leaders, religious leaders, and officials to health workers.

\section{CONCLUSION}

Children aged 7-12 years in Puro'o and Tomado villages mostly have poor behavior in preventing the transmission of schistosomiasis, either those whose occupations are at risk or those with no-risk activities, those with low or high level of education and those with adequate or inadequate knowledge. Schistosomiasis prevention needs to be informed to all children regardless of their age, sex and level of knowledge. In addition, the improvement in behavior is not solely due to high level of knowledge. Therefore, it is also necessary to study other factors that can affect behavior, such as environmental factors, socio-economic level, culture and local customs.

\section{ACKNOWLEDGMENT}

The authors would like to thank all those who have assisted in this research, with the permission and 
support given to carry out this research. The authors also thank the friends, laboratory and puskesmas staffs for their help during this research so that it can be carried out as expected.

\section{REFERENCES}

Kasnodiharjo (1997). Masalah sosial budaya dalam upaya pemberantasan schistosomiasis di Sulawesi Tengah. Cermin Dunia Kedokteran118, 40-43
Natsir AM (1992). Peran serta masyarakat dalam penanggulangan penyakit schistosomiasis di Sulawesi

Rosmini (2009). Epidemiologi dan faktor risiko penularan Schistosoma japonicum di dataran tinggi Napu Kabupaten Poso Sulawesi Tengah. A dissertation. Available from http://etd.ugm.ac.id. Accessed Juli 15, 2013.

Sudomo M (2007). Pemberantasan schistosomiasis di Indonesia. Buletin Penelitian Kesehatan 35, 3645 